\title{
Comparing Farmers' Perception of Climate Change and Variability with Historical Climate Data: The Case of Ensaro District, Ethiopia
}

\author{
Abirham Cherinet* and Zenebe Mekonnen \\ Ethiopian Environment and Forest Research Institute, Central Ethiopia Environment and Forest Research Center, Ethiopia
}

Submission: February 11, 2019; Published: February 26, 2019

*Corresponding author: Abirham Cherinet, Ethiopian Environment and Forest Research Institute, Central Ethiopia Environment and Forest Research Center, P.O. Box: 30708, Addis Ababa, Ethiopia

\begin{abstract}
This study was aimed to compare farmers' perception of climate change and variability in three kebeles of Ensaro district of Amhara Regional State of Ethiopia with 30 years meteorological data. One hundred and twenty-four sample household heads were selected, of which 22 participants were female headed households. A FGD with six participants in each kebeles were held and key informant interviews were held at the district level. Both qualitative and quantitative methods of data collection and analysis were used to compare with 30 years historical climatic data from the gridded satellite image of the study area. Also, logistic regressions were used to estimate factors that influence farmer's perception of climate change and variability and reconnaissance drought index method was used to classify drought condition of the area. The findings showed that, the average temperature of the district showed an increment by $1.02^{\circ} \mathrm{C}$ in the past three decades with an annual increment of $0.034 \mathrm{oc}$ whereas the annual rainfall of the district showed a decreasing trend with a variation of $12.7 \%$ from the mean in the period 1987 2016. In line with this, $100 \%, 87.5 \%$ and $83.3 \%$ of respondents in lowland, highland and midland agro-ecologies, respectively, perceived that temperature has shown an increasing trend and $89 \%$ of respondents recognized the decreasing trend of rainfall with shortened period of its distribution. There is an agreement between metrological data and farmers' observation that the onset of the rainy season is shifting: it was June first before ten years, and it has been extended to first week of July at present and accompanied by an increasing drought frequency. The binary model results revealed that the respondent's age, educational status, access to extension and farm experience have a positive and significant effect on farmer's perception on climate change. Moreover, farmers living in lowland agro-ecology have been aware of climate change as compared to midland and highland agro-ecologies. This is due to the fact that lowland agro-ecology is already hotter and a marginal change in temperature could be perceived easily.
\end{abstract}

Keywords: Climate change; Perception; Climate data; Barriers

\section{Introduction}

Climate change is the primary environmental issue today and will continue so in the future at a global level. United Nations Framework Convention on Climate Change [1] has defined climate changes as a change of composition of the global atmosphere that is attributed directly or indirectly to human activity in addition to natural climate variability observed over comparable time periods. In the past couple of decades, climate change has become increasingly apparent that it is already happened, happening, and will continue to happen, bringing with its local impacts on people's livelihoods [2]. The Intergovernmental Panel on Climate Change concluded that, climate variability is already happening all over the world with its multi-faceted effects on human society and the environment. Climate variability will certainly have effect on sustainable development of biodiversity, water, forests, land and oceans as well as in relation to various sectorial activities [3]. There are spatio-temporal variations in the vulnerability and adaptive capacity among countries, regions, economic sectors and social groups [4]. In this regard, all African countries are vulnerable to climate change and Ethiopia in particular is among the most vulnerable countries to climate variability with little adaptive capacity. Climatic and ecological changes have resulted in several negative consequences on livelihood, health, economy and environment of the people in Ethiopia [5]. Recurrent drought, famine and flood are the main problems that affect millions of people in the country almost every year [6]. The livelihoods of smallholder farmers are mainly dependent on agriculture and natural resource which are highly sensitive to climate change. The impact of climate change is more aggravated by poverty and the impact will be intense when it is combined with other environmental changes $[7,8]$. But it is possible to reduce adverse effects of climate change and variability by formulating effective and efficient adaptation strategies.

In different nations small holder farmers try to respond to the changing climate via different indigenous coping and adap- 
tation mechanisms [9-14]. But success of any adaptation measures would depend on a good farmers' perception about climate change and variability [15-21]. Households that have a better perception on climate variability can cope and adapt to the changing climate than those who did not perceive it [1]. Most farmers in Africa perceive the increased temperature and declined precipitation [20]. In line with this, majority of the farmers who have been contacted in Ethiopia are aware of climate change and perceived an increase in temperature and decrease in precipitation [22]. However, the perception of climate change is shaped by varying cognitive structures caused by socioeconomic and cultural differences that expose people to differing attitudes, values and interests [23]. Therefore, farmers' perceptions of climate change and variability and its effects are influenced by psychological and socioeconomic differences which will limit their response to climate change [24]. In the past, many different studies were done in different corners of Africa with regards to human perception of climate change and its impacts [25-28] and most of them have confirmed that, the farming community perceived the changing of climate and trying to implement soft and hard adaptation strategies [24,29]. However, perceived changes may not always reflect the reality, and climatic events or trends may be misinterpreted or wrongly remembered for a variety of reasons. Therefore, it is necessary to assess and analyze farmers' perception of climate change and variability and what did climate data really showed. So, this paper tried to assess and compare farmers' perception with metrological data in the study area.

\section{Research Methodology}

\section{Description of the study area}

Ensaro district is one of the 24 districts which are found in North Showa Zone of Amhara Regional State in Ethiopia. Geographically, the district is located between 9o $35^{\prime}-9^{\circ} 5^{\prime} \mathrm{N}$ and $38^{\circ}$ $50^{\prime}-39^{\circ} 5^{\prime} \mathrm{E}$ with an average elevation of 2435 meters above sea level. The district has one urban kebele and eleven rural kebeles. Based on the 2007 national census conducted by the Central Statistical Agency (CSA) of Ethiopia, the district has a total population of 58,203 , of which 29,888 were male and 28,315 female; $3,164(5.44 \%)$ were urban inhabitants. The district's total land coverage is $44,217.6$ hectare including undulating areas covering about $50 \%$, flat plains $40 \%$, mountainous and others $10 \%$. According to the district's administration office and community classification, the district's agro-ecology is subdivided into lowland (33\%), midland (46\%) and highland (21\%). The vegetation is dominated by scattered trees such as the Croton macrostachyus, Olea capensis, Euclea schimperi, acacias (Acacia spp.), Eucalyptus viminalis and Eucalyptus globules etc. The area is also characterized by a bimodal rainfall distribution with a distinct rainy season lasting from May to September. The average annual rainfall varies between 900 to $1500 \mathrm{~mm}$ and average temperature is in between $18^{\circ} \mathrm{C}-30^{\circ} \mathrm{C}$. Although agriculture is the main economic activity, many households are engaged in activities such as trading, selling of fire wood and charcoal and livestock rearing which constitute the main source of cash income (Figure 1).

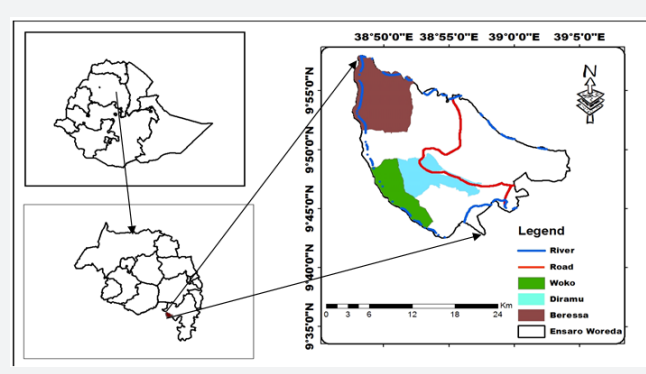

Figure 1: Map of the study area

\section{Sampling and sample size}

The sample kebeles were purposively selected from all agro-ecological zones of the district: Beressa kebele from Lowland, Woko kebele from midland and Diremu kebele from Highland agro ecologies. Climate change hazards like flood, drought and landslide are more severe in the selected kebeles of the district. The participants in this study included: the local people (male and female including youths), government representative, and religious leaders of sample kebeles, and concerned officials from the district. The sample size was $124(10 \%)$ out of 1232 total household heads in the sampled kebeles. Both primary and secondary data sources were used. The primary data were collected through questionnaire, interview and focused group discussion. The researcher selected FGD and KI respondents in each kebele who are socially respected within society and are known to have better knowledge on the present and past environmental, social and economic status of the study area. At each kebele, one focus group discussion was held with 6 participants in each discussion group and key informant interviews with 10 community representatives. Secondary data were collected from published and unpublished documents identified from government offices, National Meteorological Service Agency (NMSA), Central Statistical Agency and Addis Ababa University. Gridded satellite data was used for the monthly rainfall and maximum and minimum temperature for the period $1987-2016$.

\section{Data analysis and presentation}

Data obtained from various sources were analyzed using qualitative and quantitative data analysis techniques. The Qualitative data were narrated and interpreted. The quantitative information gathered using interviews were analyzed using SPSS Version 23.0 statistical software. Errors related to inconsistency of data were checked and corrected during data cleaning. In addition, the quantitative data generated by questionnaire and from ENMSA gridded data had been analyzed using descriptive statistics. Descriptive statistics such as mean, frequency and percentage were used to characterize farmer's perception on long-term temperature and precipitation variability as well as various adaptation measures used by farmers, and barriers they face to adapt. Binary logit mod- 
el was used to see the relationships between dependent and independent variables and reconnaissance drought index was used to characterize the drought condition of the study area.

\section{Result and Discussion}

\section{Average annual Temperature}

The average temperature of the study area has increased by $1.02^{\circ} \mathrm{C}$ in the period 1987-2016 with an annual increment of $0.034^{\circ} \mathrm{C}$ (Figure 2). On the other hand, maximum and minimum temperatures have increased by $1.5^{\circ} \mathrm{C}$ and $0.5^{\circ} \mathrm{C}$ respectively in the past three decades. Such trend of increase in temperature in the Ethiopian highlands is also reported [30].

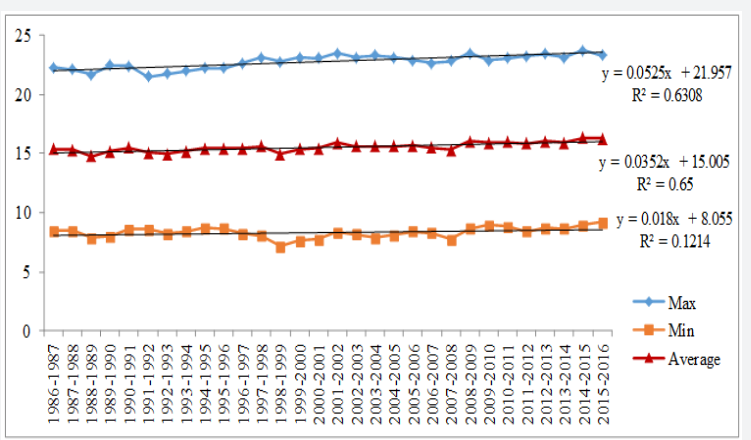

Figure 2: Trend of maximum annual average temperature in the period 1987-2016 in the study area

\section{Average monthly and annual rainfall}

The average annual rainfall of Ensaro district over the last three decades indicated somehow a decreasing trend (Figure 3). The annual average rainfall was $1175 \mathrm{~mm}$, with the maximum of $1487 \mathrm{~mm}$ record in 1996, whereas the smallest average rainfall $(764 \mathrm{~mm})$ was recorded in 2015 .

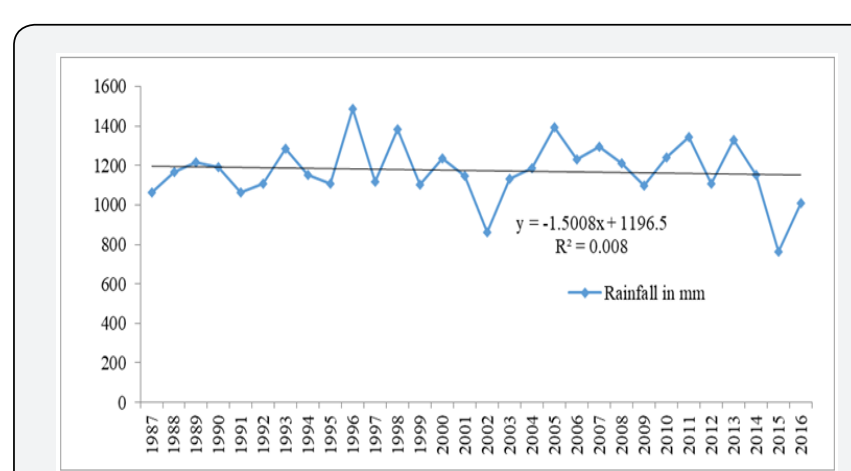

Figure 3: Annual rainfall patterns and trends of variability for the period 1987-2016 in the study area

Monthly rainfall distribution in the last three decades of the study area showed that, there was a prevalence of rainfall across months. Nearly $67 \%$ of the total amount of rainfall was recorded between July and September. The monthly pattern of rainfall distribution starts to decline from October until March that clearly reflects the prevalence of seasonality of rainfall in the study area (Figure 4).

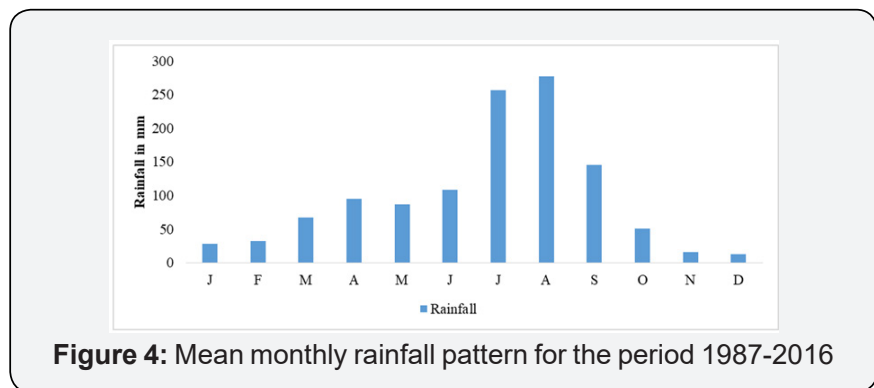

\section{Seasonal rainfall patterns}

The analysis of seasonal rainfall in the study area showed a small/negligible variability with $\mathrm{R}^{2}$ ranging from 0.014 for MarchApril-May (MAM) -Ethiopian spring season — to 0.037 for JuneJuly-August (JJA) - Ethiopian summer season-during the period 1987-2016. In the same period, the rainfall has declined by 0.49 and $0.51 \mathrm{~mm}$ per annum for MAM and DJF- Ethiopian spring season and winter seasons-respectively (Figure 5).

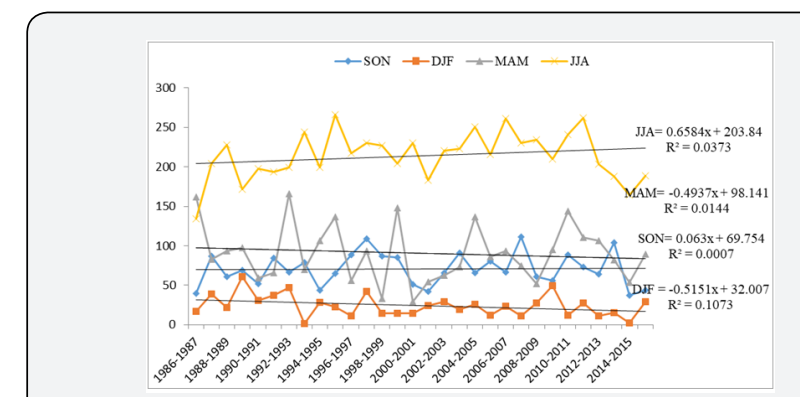

Figure 5: Seasonal rainfall pattern for the Period 1987-2016

\section{Community perceptions of climate change and vari- ability}

Having better understanding of local people's perception on climate change and variation is crucial to design appropriate adaptation and coping strategies [31]. It is important to have an insight of local people's view on temperature and rainfall trends of change to screen locally available climate change and variability adaptation options. In line with this, FGD participants, key informants and respondents were asked to tell their understanding of climate change and source of information. About $95 \%$ of male and $55 \%$ of female respondents confirm that, there is climate change and variation in their locality. More than $69 \%$ of male and $59 \%$ of female respondents have had information on climate variation and the major source of information are radio, development agents and market places. Regarding to the perception of community to climate variability, majority of participants perceived the existence of the problem and their perception also related with their socio demographic variables.

\section{Perception by Agro-Ecology and sex of household heads}

People who live in lowland agro-ecology have perceived more because lowlands are already hotter and a marginal change in temperature can be perceived more easily [32]. In line with this, the result of this research also showed that farmers in lowland agro-ecology $(92.8 \%$ of male and $66.7 \%$ of female from the sam- 
ple) are more aware on climate change than farmers in midland (79.5\% of male and $55.6 \%$ of female). About $77 \%$ of male and $43 \%$ of female respondents are aware of climate change in highland agro-ecology. The result showed that female headed households are perceived less because they are less access to information, technology and mobility. In contrary, male headed farmers have access to information due to mobility, decision making and their participation in training. In general, about $95 \%$ of male and $55 \%$ of female (88\% of total the respondents) in all agro-ecologies are aware of climate change, while about $12 \%$ of respondents have no information or didn't have the knowledge of climate change.

\section{Perception by age group}

According to Amadou [33], farmers with high experience are more perceived climate change. In line with his argument, $60 \%$, $89 \%$ and $94 \%$ participants found under age 20-40, 41-60 and $>60$ have understood the existence of climate variability in their kebeles respectively. The elder respondents perceived climate change very well due to their long experience in the area. Previous studies also indicate that, perception will increase when age of a household increases [22].

\section{Perception by education level}

Out of 45 illiterate respondents, $64.4 \%$ of them have observed the existence of climate variability, while $75 \%$ of those who read and write, $89.5 \%$ of those who reached primary school and $100 \%$ of the respondents that reached secondary school have perceived the existence of climate change and variability. The result showed that about $36 \%$ of the respondents that didn't perceived the existence of climate change and variability were illiterate and followed by those who have only informal education (25\%). The educational level of farmers has a direct link with the perception to climate change and variability. Farmers with relatively higher education levels have opportunities to get information from schools, environmental clubs and other sources of information. Thus, farmers with higher educational level have better perception than farmers with lower levels of education.

\section{Farmers' perception on temperature and rainfall vari- ability}

The result revealed that most of the respondents have perceived as there was long-term variability in temperature in Ensaro district over the past three decades. Almost 100\%, 88\% and 84\% of the respondents in lowland, highland and midland agro-ecologies, respectively, have perceived that temperature is increased from year to year. On the other hand, about $13 \%$ and $17 \%$ of the respondents in midland and highland agro-ecologies felt that there is no change in temperature. The indicators of temperature variability perceived by the respondents were drying up of rivers and streams, crop damage by pests, newly introduced human and animal disease, and species shift to upper altitude, and introduction of new plant and animal species.

Key informant interviewees and FGDs discussants have recognized as there were variability in rainfall amount, its timing and distribution in the study area over the past 30 years. This was substantiated by household respondents. About $97 \%$ of the respondents in lowland agro-ecology have recognized the change (the increase or decrease) of rainfall amount, while only $42 \%$ and $22 \%$ of respondents in midland and highland agro-ecologies have perceived rainfall change respectively. This shows that climate change is more pronounced in areas already have climatic problem. The survey results revealed that all the respondents have perceived long-term variability in pattern of rainfall amount and distribution. Most of the respondents indicated that rainfall amount in Ensaro district in the last 30 years showed a decreasing trend and variability whereas only few of the respondents reported that it has increased. The local community perceived the shift in the beginning of the spring rainfall from March to May. The perceived impacts of such variability in rainfall include emergence of pests and disease, interruption in crop calendar of such spring crop production for root crops and vegetables, death of livestock.

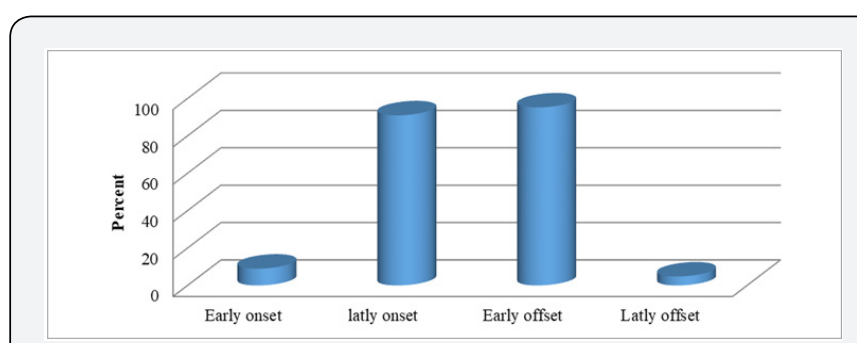

Figure 6: Perception on rainfall onset and offset

About $94 \%$ of interviewed farmers indicated that there is a long-term change in the start and end of the rainy season in the study area (Figure 6). About $91 \%$ of the respondents indicated that the onset of the rainy season has been shifted from the first week of June before 10 years ago to the first week of July in the current year. Its only $9 \%$ of the respondents reported that the dates of the onset are early. On the other hand, the end of the rainy season has shifted from October $1^{\text {st }}$ week what was before $10-30$ years ago to the $1^{\text {st }}$ week of September and last week of August in current year which was agreed by $95 \%$ of the respondents. It was only $5 \%$ of the respondents who have a thought that the rainy season was ending late.

\section{Drought prevalence}

Climate changes will most likely increase poverty in Ethiopia [34]. Long term trends towards reduced rainfall, and recurring droughts, have played a role in weakening of Ethiopian economy [35]. About $94 \%$ of the respondents have well recognized the prevalence of drought in lowland agro-ecology, while nearly $63 \%$ in midland and $26 \%$ of the respondents in highland agro-ecologies have perceived the prevalence of drought (Figure 7). On the other hand, the increment of the frequency of drought is more perceived by respondents in lowland agro-ecology (89\%) than respondents in midland (60\%) and highland (23\%) agro-ecologies. This shows that, climate change was not a problem in the highland agro-ecology of the study district. The results from the Reconnaissance Drought Index (RDI) showed that, there was an extreme drought 
condition in 2015-2016 in Ensaro district with severe and moderate drought conditions in 2002-2003 and in 2016-2017 respectively.

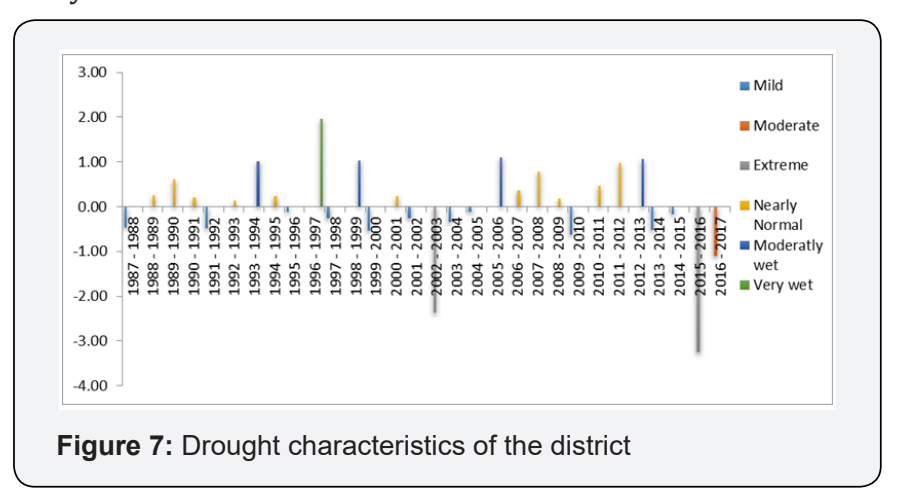

\section{Determinants of perception of climate change}

A large number of local people consider that climate has become hotter and drier. All the respondents and most of the FGDs participants, experts and interviewed informants perceived changes in temperature and precipitation. The binary model results revealed that the respondent's age, educational status, access to extension and farm experience have a positive and significant effect on farmer's perception on climate change and adaptation. The results showed that a unit increase of the variables significantly increase the odds of having a good perception of climate change and variability (Table 1). On the other hand, sex of household heads, access to extension services, farm land size, access to market and access to credit have negative and significant effect on farmers perception on climate change in the study area.

Table 1: ANOVA: Factors that affect Farmers perception on climate change from binary logit model.

\begin{tabular}{|c|c|c|c|c|c|c|c|c|c|c|}
\hline \multirow{2}{*}{ Factors } & \multicolumn{2}{|c|}{$\begin{array}{c}\text { Attitudes on Climate } \\
\text { Change }\end{array}$} & \multicolumn{2}{|c|}{$\begin{array}{c}\text { Feeling of Tempera- } \\
\text { ture }\end{array}$} & \multicolumn{2}{|c|}{ Rainfall Change } & \multicolumn{2}{|c|}{$\begin{array}{c}\text { Encountering of Crop } \\
\text { Failure }\end{array}$} & \multicolumn{2}{|c|}{ Occurrences of Drought } \\
\hline & $\mathrm{B}(\mathrm{S})$ & $\operatorname{Exp}(B)$ & $\mathrm{B}(\mathrm{S})$ & $\operatorname{Exp}(B)$ & $\mathrm{B}(\mathrm{S})$ & $\operatorname{Exp}(B)$ & $\mathrm{B}(\mathrm{S})$ & $\operatorname{Exp}(B)$ & $B(S)$ & $\operatorname{Exp}(B)$ \\
\hline Age & $0.197(.550)$ & 1.302 & $.033(.490)$ & 1.356 & $.759(.622)$ & 2.135 & $.334(.735)$ & 1.396 & $1.883(.074)$ & 6.572 \\
\hline Sex & $-1.015(.292)$ & 0.759 & $-0.03(.975)$ & 0.029 & $-0.5(.599)$ & 0.694 & $-.469(.432)$ & 0.626 & $-0.536(.346)$ & 0.71 \\
\hline Education & $0.784(.018)$ & 2.062 & $-.069(.865)$ & 0.934 & $-.97(.225)$ & 0.379 & $.611(.082)$ & 1.842 & $.200(.574)$ & 1.222 \\
\hline $\begin{array}{l}\text { Family } \\
\text { Size }\end{array}$ & $-0.617(.111)$ & 0.854 & $.103(.712)$ & 1.108 & $.044(.890)$ & 1.045 & $.612(.003)$ & 1.542 & $.120(.351)$ & 1.887 \\
\hline $\begin{array}{l}\text { Access to } \\
\text { Extension }\end{array}$ & $.937(.308)$ & 1.392 & $-.125(.903)$ & 0.883 & $-.1(.894)$ & 0.905 & $.273(.587)$ & 1.314 & $.897(.063)$ & 2.453 \\
\hline $\begin{array}{l}\text { Farm Land } \\
\quad \text { Size }\end{array}$ & $-0.257(.826)$ & 0.293 & $-.640(.488)$ & 0.527 & $-.407(.709)$ & 0.502 & $-.661(.277)$ & 0.516 & $-.352(.551)$ & 0.703 \\
\hline $\begin{array}{l}\text { Access to } \\
\text { Informa- } \\
\text { tion }\end{array}$ & $-.310(.745)$ & 0.364 & $-1.27(.022)$ & 0.569 & $.393(.683)$ & 1.481 & $.409(.527)$ & 1.506 & $-1.269(.048)$ & 0.281 \\
\hline $\begin{array}{l}\text { Access to } \\
\text { Credit }\end{array}$ & $0.888(.398)$ & 2.431 & $-.479(.659)$ & 0.619 & $.970(.339)$ & 2.639 & $-.724(.353)$ & 0.485 & $.354(.090)$ & 1.258 \\
\hline $\begin{array}{l}\text { Farm Ex- } \\
\text { perience }\end{array}$ & $.289(.881)$ & 1.336 & $-.991(.539)$ & 0.371 & $1.34(.461)$ & 3.832 & $.239(.816)$ & 2.787 & $.784(.461)$ & 1.456 \\
\hline $\begin{array}{c}\text { Extra } \\
\text { Income }\end{array}$ & $1.286(.402)$ & 3.617 & $-.501(.552)$ & 0.606 & $-.06(.966)$ & 0.058 & $1.256(.077)$ & 3.513 & $.715(.291)$ & 2.043 \\
\hline $\begin{array}{c}\text { Access to } \\
\text { Market }\end{array}$ & $-.086(.919)$ & 0.917 & $-.761(.433)$ & 0.467 & $-.80(.360)$ & 0.232 & $-.105(.867)$ & 0.9 & $.702(.252)$ & 2.017 \\
\hline Constant & $-4.338(.365)$ & 0.013 & $2.079(.680)$ & 7.999 & $-8.9(.051)$ & 0 & $1.326(.684)$ & 3.767 & $-2.059(.463)$ & 0.128 \\
\hline
\end{tabular}

$\operatorname{Exp}(B)====$ odd ratio $S========$ significant

\section{Farmers' perception VS empirical meteorological data}

Individual's perception of climate change is highly personal, place-based, and influenced by a number of factors. This paper tried to see how farmers perceptions of climate change are related to historical trends in climate. Farmer perceptions of climate change varied considerably and were not systematically consistent with the direction and significance of climate trends calculated from the observational record, lending support to the idea that other personal and environmental factors are important for determining perceptions. In this regard, like any farmer in every developing country, the majority of farmers in the study area be- lieve that the climate has changing. The respondents claimed that temperature has increased, and rainfall has decreased through time. The study by Mekonnen et al. [25] in Arsi Negele district of the central rift valley of Ethiopia showed that the total average temperature shows an increasing trend while the rainfall shows a decreasing trend. In line with this argument, almost $100 \%$, $88 \%$ and $83 \%$ of respondents in lowland, highland and midland agro-ecologies, respectively, have perceived that temperature is increased from year to year. On the other hand, the meteorological data indicated that the average temperature of the study area has increased by $1.02^{\circ} \mathrm{C}$ in the past 30 years with an annual increment of $0.034^{\circ} \mathrm{C}$. In regard to rainfall, about $97 \%$ of the respondents in lowland agro-ecology have recognized the change (the increase or 
decrease) in rainfall amount, while only $42 \%$ and $22 \%$ of respondents in midland and highland agro-ecologies, respectively, have perceived rainfall changes over the last three decades. Some of the mentioned reasons for their perception of the long term decrease in rainfall were day-to-day experiences with rainfall variability, increasing dry spells, time shifts in onset and offset of rainfall and its distribution rather than on average quantities of annual rainfall. However, the actual data have not shown a significant change in trend, especially rainfall. On the other hand, about $94 \%$ of the respondents in lowland agro-ecology have well recognized the prevalence of drought, while nearly 63 and $26 \%$ of the respondents in midland and highland agro-ecologies, respectively, have perceived the prevalence of drought. The increasing frequency of drought was more perceived by respondents in lowland agro-ecology. The results from the Reconnaissance Drought Index (RDI) showed that, there was an extreme drought condition in 2015-2016 in Ensaro district with severe and moderate drought conditions in 2002-2003 and in 2016-2017 respectively.

The results of the regression analysis showed that age, educational status, access to extension and farm experience have a positive and significant influence on farmers' perception of climate change and variability. This positive relationship between the perception of climate change and access to extension services indicates that having extension advice is very likely to increase the farmers' awareness of climate change and variability [36]. Although getting extension services would help to build farmers' knowledge, they still had their own perception on climate change [37]. In addition, farmers' perception of the local environment could be related to the topography of the area which exerts a strong influence in the agro-ecology. In line with this, farmers living in lowland areas were more likely perceived climate change than those in the midlands and highlands [36]. The results of this study showed that farmers in lowland agro-ecology have better perception on climate variability than farmers in highland agro-ecology.

\section{Conclusion}

Most of the respondents, FGD and KI participants indicated that, temperature is becoming increasing from time to time in the past three decades in the district and rainfall is in a decreasing trend in amount, duration and intensity. A number of farmers in the study area are aware on the late onset and early offset of rains and the increasing drought frequency which are in accord with empirical meteorological records. However, farmers give much more importance to the intra-annual variability of rainy season characteristics such as rainfall intensity and distribution than the total annual rainfall. Moreover, there are several factors that determine farmers' perception on climate change. The results of binary logit model have revealed that the respondent's age, educational status, access to extension and farm experience have a positive and significant effect on farmer's perception on climate change and/or variability. The results of the study direct the need in capacity development programmes like climate -smart agro ecosystem management trainings for farmers to cope with the changing climate. Therefore, the government could build the capacity of agricultural extension systems and strengthen climate change education scheme $[24,38]$ with ICT innovations such as cell phone applications and up to date early warning system by integrating information from both the ingenious and scientific climate prediction methods.

\section{Acknowledgement}

The authors would like to thank Ethiopian Environment and Forest Research Institute for providing the financial support to carry-out this research. The other special thanks go to Ensaro district Agricultural Development Office staffs, interviewees, FGD and KI participants for their valuable contributions of this research.

\section{References}

1. UNFCCC (2007) Climate change: Impacts, vulnerabilities and adaptation in developing countries. Climate Change Secretariat (UNFCCC): Bonn, Germany.

2. Parry ML, Canziani OF, Palutikof J, Linden P, Hanson C (2007) Climate change: Impacts, adaptation and vulnerability. Contribution of Working Group II to the Fourth Assessment report of the Intergovernmental Panel on Climate Change. Cambridge University Press, Cambridge, UK, p. 976.

3. WMO (1992) Climate change, Environment and Development: World Leaders viewpoints. Secretariat of WMO. Geneva, Switzerland. No. 772.

4. IPCC (2001) Climate Change Impacts, Adaptation and Vulnerability. IPCC Working Group II, Third Assessment Report. Cambridge, Cambridge University Press, USA.

5. Eriksson M (2006) Climate Change and its Implications for Human Health in the Himalaya. Sustainable Mountain Development in the Greater Himalayan Region, p. 50.

6. NMSA (2007) Climate change: National Adaptation Program of Action (NAPA) of Ethiopia. Ministry of Water Resource, Addis Ababa.

7. Mertz O, Mbow C, Reenberg A, Diouf A (2009) Farmers' perceptions of climate change and agricultural adaptation strategies in rural Sahel. Environ Manage 43(5): 804-816.

8. IPCC (2014) Climate change 2014: Synthesis report. Contribution of working groups I, II and III to the fifth assessment report of the intergovernmental panel on climate change. In: Pachauri RK, Meyer LA (Eds.), Geneva: IPCC, p.151.

9. Gyampoh BA, Amisah S, Idinoba M, Nkem J (2009) Using traditional knowledge to cope with climate change in rural Ghana. In Unasylva 231/232 60: 70-74.

10. NAC (National Academy of Science) (2010 Adapting to the impacts of climate change. Washington, D.C.: The National Academies Press, USA, p. 292.

11. Osbahr H, Peter Dorward P, Stern R, Cooper S (2011) Supporting agricultural innovation in Uganda to respond to climate risk: Linking climate change and variability with farmer perceptions. Agricultural Innovation and Climate Risk 47(2): 293-316.

12. Kumar V (2014) Role of Indigenous knowledge in climate change adaptation strategies: A study with special reference to North-Western India. Geography \& Natural Disasters 4: 131.

13. Tilahun U, Bedemo A (2014) Farmers' perception and adaptation to climate change: Heckman's two stage sample selection model. 
Ethiopian Journal of Environmental Studies \& Management 7(2): 832839

14. Huda MN, Hossin MZ, Ashik E Elahi S, Mahbub F (2016) Sociodemographic and economic correlates of climate change coping and adaptation strategies: A study on the farmer communities in Barisal district, Bangladesh. American Journal of Climate Change 5(2): 167177

15. Okonya JS, Syndikus K, Kroschel J (2013) Farmers ' Perception of and Coping Strategies to Climate Change : Evidence From Six AgroEcological Zones of Uganda. Journal of Agricultural Science 5(8): 252263

16. Simelton E, Quinn CH, Batisani N, Dougill AJ, Jen C, et al. (2013) Is rainfall really changing? Farmers perceptions, meteorological data and policy implications. Clim Dev, pp. 37-41.

17. Moyo M, Mvumi BM, Kunzekweguta M, Mazvimavi K, Craufurd P, et al. (2012) Farmer perceptions on climate change and variability in semi-arid Zimbabwe in relation to climatology evidence. African Crop Science Journal 20(2): 317-335.

18. Penaranda I, Perrino ES, Barreras E (2012) Farmers Perceptions of Climate Change: A Case Study in the Abura-Aseibu-Kwamankese district, Central Region, Ghana.

19. Gbetibouo GA (2009) Understanding Farmers ' Perceptions and Adaptations to Climate Change and Variability: The Case of the Limpopo Basin, South Africa. In: International Food Policy Research Institute, p. 52.

20. Temesgen T (2007) Measuring the economic impact of climate change on Ethiopian agriculture: Ricardian approach. World Bank Policy Research Paper No. 4342. World Bank, Washington D.C, USA

21. Maddison D (2006) The perception of and Adaptation to Climate Change in Africa. In: Special Series on Climate Change and Agriculture in Africa ISBN 1-920160-01-09. Discussion Paper ISBN 1-920160-108, 1-47. Pretoria: Centre for Environmental Economics and Policy in Africa, University of Pretoria, South Africa.

22. Temesegen T (2009) A study on the perception and adaptation to climate change: The case of farmers in the Nile Basin of Ethiopia. Centre for Environmental Economics and Policy for Africa (CEEPA), University of Pretoria, South Africa.

23. Weber EU (2010) What Shapes Perceptions of Climate Change? Clim Chang 1(3): 332-342.

24. Evans LS, Hicks CC, Adger WN, Barnett J, Perry AL (2016) Structural and Psycho-Social Limits to Climate Change Adaptation in the Great Barrier Reef Region. PLoS One 11(3): e0150575.

25. Zenebe M, Habtemariam K, Teshale W, Zebene A (2017) Analysis of observed and perceived climate change and variability in Arsi Negele
District, Ethiopia. Environment, Development and Sustainability 20(3): 1191-1212.

26. Bekele S, Kindie T, Menale K, Tsedeke A, Prasanna BM, et al. (2014) Managing vulnerability to drought and enhancing livelihood resilience in sub-Saharan Africa: Technological, institutional and policy options. Weather and Climate Extremes 3: 67-79.

27. Bewket W (2012) Climate change perceptions and adaptive responses of smallholder farmers in central highlands of Ethiopia. International Journal of Environmental Studies 69: 507-523.

28. Hausken ME (2004) Contrasting climate variability and meteorological drought with perceived drought and climate change in northern Ethiopia. Climate Research 27(1): 19- 31.

29. Ayal D, Muluneh A (2014) Smallholder farmers' vulnerability to climate variability in the highland and lowland of Ethiopia: implications to adaptation strategies. Doctoral thesis, University of South Africa, Geography Department.

30. Muna H (2006) Variation and trends in observed temperatures in the Ethiopian highlands (1973-2003). M.A Thesis, Addis Ababa University, Ethiopia.

31. Demeke H (2010) Climate variability and change impact on rural livelihoods, and local adaptation and coping strategies: The case of Wereilu wereda, south Wollo zone, Amhara region. M.A. Thesis, Addis Ababa University, Ethiopia.

32. Deressa (2010) Factors affecting the choices of coping strategies for climate extremes: the case of Farmer's in the Nile Basin of Ethiopia.

33. Amadou ML, Villamor GB, Attua EM, Traoré SB (2015) Comparing farmers' perception of climate change and variability with historical climate data in the Upper East Region of Ghana. Ghana Journal of Geography 7(1).

34. Mideksa TK (2010) Economic and distributional impacts of climate change: the case of Ethiopia. Global Environmental Change 20(2): 278286.

35. USAID (2004). Breaking the cycle of food crises: famine prevention in Ethiopia

36. Deressa T, Hassan R, Ringler C (2008) Assessing household vulnerability to climate change: The case of farmers in the Nile Basin of Ethiopia. IFPRI discussion paper 00935. Addis Ababa Ethiopia.

37. Yaro JA (2013) The perception of and adaptation to climate variability/ change in Ghana by smallscale and commercial farmers. Reg Environ Chang 13(6): 1259-1272.

38. Ayanlade, Jegede (2016) Comparing smallholder farmers' perception of climate change with meteorological data: A case study from southwestern Nigeria.

Your next submission with Juniper Publishers will reach you the below assets

- Quality Editorial service

- Swift Peer Review

- Reprints availability

- E-prints Service

- Manuscript Podcast for convenient understanding

- Global attainment for your research

- Manuscript accessibility in different formats

(Pdf, E-pub, Full Text, Audio)

- Unceasing customer service

Track the below URL for one-step submission https://juniperpublishers.com/online-submission.php 